\title{
1 Bacterial Community Shift in Marine Tar Balls following Low Salinity Exposure
}

2 Mai Hoang Tran and Joong-Wook Park

3 Department of Biological and Environmental Sciences, Troy University, Troy, AL 36082, USA

4 Corresponding author: Joong-Wook Park, jwpark@troy.edu, Tel. 334-808-6416, Fax. 334-670-3662

$5 \quad$ Running title: Low salinity affects bacterial community in tar balls

7 Abstract: The persistence and recurrence of tar balls causes detrimental effects on coastal wildlife, tourism, and

8 fisheries. Previously, the human pathogen Vibrio vulnificus was detected in marine tar balls in the Gulf of Mexico.

9 Marine tar balls also migrate to low-salt water bodies near the shore. The bacterial communities in tar balls from these 10 environments, however, have not been fully characterized. Herein we describe our studies on the effect of reduced

11 salinity on bacterial communities in marine tar balls. Tar balls collected from the Gulf of Mexico were incubated in 12 deionized water for six months, and their microbial fingerprints were visualized using denaturing gradient gel 13 electrophoresis. Our data show that the indigenous bacterial communities in marine tar balls shifted after being 14 exposed to low-salinity condition. Dominant genera in the tar balls at low salinity were Aquisalimonas and 15 Parvibaculum, neither of which includes known human pathogens.

16 Keywords: tar balls; salinity; estuarine; bacterial community; oil spill

\section{1. Introduction}

After being released into the ocean, petroleum hydrocarbons undergo multiple weathering processes, including evaporation, emulsification, dissolution, and oxidation [1]. Tar balls are a form of weathered oil occurring in discrete

20 pieces of about $10 \mathrm{~cm}$ or less in diameter that can be washed onto beaches, float in water, or lie on the seafloor [1,2].

21 Tar balls consist of a hard outer crust and a sticky semisolid core [3, 4]. The weathered oil in tar balls contains high

22 concentrations of recalcitrant oil remnants such as long-chain alkanes ( $\mathrm{n}>16)$, polycyclic aromatic hydrocarbons, and

23 oxygenated hydrocarbons [5, 6]. In addition to the weathered tar balls, oil mats formed after oil spills under the ocean

24 can be broken into small pieces by storms or hurricanes, producing less-weathered forms of tar balls [7]. Much effort

25 has been made to clean the Gulf of Mexico after the Deepwater Horizon (DH) oil spill in 2010, but tar balls still 26 reappeared after subsequent storms or hurricanes, causing recurrent problems along the Gulf coast. 
The persistence of tar balls in ecosystems is a threat to coastal wildlife, tourism, and fisheries [8]. Recent research found that the DH-oil-spill-related tar balls contained stable free radicals and genotoxic metals such as chromium and nickel $[9,10]$, posing risks to human health. Additionally, a study by Tao et al. in 2011 showed that there was a 100fold higher accumulation of Vibrio vulnificus, a human pathogen, in tar balls collected on the Gulf coast, compared to samples collected from sea water or sand [11]. This result suggests that the unique chemical and physical features of tar balls can create a niche for certain bacterial species, including human pathogens.

In October 2010, tar balls from the DH oil spill drifted to Lake Pontchartrain, an estuary on the Gulf coast [12, 13]. communities $[14,15]$. Previous studies demonstrated that there were variations in microbial communities in water samples along a salinity gradient [16-18]. To the best of our knowledge, no research has been conducted on tar ball bacterial communities as they are exposed to low salinity environments. Given the fact that tar balls can nurture human pathogens [11], it is crucial to study the tar ball bacteria in estuarine environments. Here we investigated the bacterial community shift and dominant bacterial species in tar balls on exposure to low salinity condition.

\section{Materials and Methods}

Sampling, microcosm preparation and DNA extraction. Tar ball samples were collected in September, 2012, immediately after Hurricane Isaac at Alabama beach (N30 $14^{\prime} 30.23 "$, W $\left.87^{\circ} 43^{\prime} 41.90^{\prime \prime}\right)$ and stored at $4{ }^{\circ} \mathrm{C}$ for microcosm study and at $-20^{\circ} \mathrm{C}$ for initial bacterial community analysis. A microcosm was set up in October 2012 by placing tar balls with an equal volume of sterilized deionized water in a sterilized bottle. The tar balls were sampled after six months of incubation at $35^{\circ} \mathrm{C}$ without shaking. The salinity of the microcosm was $495 \mathrm{ppm}$ and the $\mathrm{pH}$ of the microcosm was 6.5. Total DNA was extracted from $0.5 \mathrm{~g}$ of tar ball samples using PowerSoil ${ }^{\mathrm{TM}}$ DNA Isolation ${ }^{\circ} \mathrm{C}$ prior to analysis.

Polymerase chain reaction (PCR). The primer set 341F with GC clamp and 534R was used to selectively amplify the V3 region of 16S rRNA gene from the total DNA [19]. One $\mu \mathrm{L}$ from each total DNA sample was mixed with 10 pmol of each primer, $0.25 \mathrm{mM}$ of dNTP, $5 \mu \mathrm{L}$ of $10 x$ Green Taq PCR buffer, and $1 \mu \mathrm{L}$ of Green Taq DNA

52 polymerase to make a $50 \mu \mathrm{L}$ PCR mixture (GenScript, Piscataway, NJ). PCR was set for initial denaturation at $95{ }^{\circ} \mathrm{C}$ 
54 at $72{ }^{\circ} \mathrm{C}$. The reactions were finished with a final extension at $72{ }^{\circ} \mathrm{C}$ for 7 minutes. The amplification products were checked for integrity using $1.5 \%$ agarose gel electrophoresis.

Denaturing gradient gel electrophoresis (DGGE). Eight percent polyacrylamide gels were cast with a linear

57 denaturing gradient of $40 \%$ on the top and $60 \%$ on the bottom. An equal volume of the PCR products from each sample was subjected to DGGE electrophoresis on a Bio-Rad DCode ${ }^{\mathrm{TM}}$ system at $45 \mathrm{~V}$ for 16 hours in $1 \mathrm{x}$ Tris-acetate EDTA buffer (TAE, pH 8.0) (Bio-Rad Laboratories, Hercules, CA). Immediately after electrophoresis, the gels were stained with ethidium bromide and placed on a UV transilluminator for photographing (Fisher Scientific, Pittsburgh, PA).

DGGE band excision and DNA sequencing. Selected DGGE bands were excised and submerged in $50 \mu \mathrm{L}$ of deionized water for 24 hours. One $\mu \mathrm{L}$ of the supernatant containing the eluted DNA was used as template DNA for subsequent PCR-DGGE procedure (using the same experiment conditions as described above) to screen the purity of the excised DGGE band. When necessary, this process was repeated until one single DGGE band of interest was detected on the gels. The final PCR products were purified using MEGAquick-spin ${ }^{\mathrm{TM}}$ Total Kit (iNtRON Biotechnology Inc., Korea) according to the manufacturer's instructions. The clean partial 16S rRNA gene amplicons were sequenced with forward and reverse primers separately by Genewiz Inc. (Genewiz Inc., South Plainfield, NJ). Each set of forward and reverse sequences was assembled into a consensus sequence using the DNA Subway program gene sequences in GenBank DNA libraries using Basic Local Alignment Search Tool (BLAST) [20].

Gel Image Processing. Bionumerics version 7.6 platform was used to identify the bands and measure their intensity with respect to the background noise (Applied Maths, Austin, Texas).

\section{Results and Discussion}

Our data show that indigenous bacterial communities in marine tar balls shifted when exposed to a low salinity condition. Indigenous bacterial populations were decreased (bands A, B, and C), not changed (band D), or increased

77 (band E) after 6 months of incubation in sterilized deionized (DI) water (Fig. 1). Since no microorganisms were introduced in the microcosm, all bacteria thriving in the tar ball samples were indigenous bacteria. Considering that 
81 in the tidal fresh zone. A steep reduction in salinity from the seawater to the tidal fresh zone is considered to have

82 triggered the bacterial community shift in the marine tar balls. Our observation was consistent with previous literature that showed different microbial diversity along salinity gradients in estuaries $[17,18]$ and a study reporting unique hydrocarbon-enriched bacterial communities established in response to changed salinity levels [16]. However, the studies mentioned above used water samples, while our research tested marine tar balls collected from the Gulf of Mexico.

DGGE bands $\mathrm{A}, \mathrm{B}$, and $\mathrm{C}$ represent bacterial species dominant in marine tar balls, with their populations diminishing under low salinity conditions (Fig. 1). The DNA sequence of band A had an $85 \%$ match in identity with the 16S rRNA gene of Methylocystacceae bacterium strain PKR-39 (Table 1), a type II methanotroph originally isolated from rhizosphere soil. Methanotrophic phylotypes were previously identified at the Gulf coast after the DH oil spill [22-24]. The presence of methanotrophs suggests hydrocarbons in the tar balls had been degraded into methane by methanogenic microorganisms $[25,26]$ when the tar balls were on the Gulf coast. DNA sequencing data of bands B and C showed that they belonged to members of the families Sphingomonadaceae (band B) and Rhodobacteraceae (band C), both of which are well-known marine taxa with an ability to degrade oil [27-29]. Multiple studies have found these taxa dominating in coastal water and sediments along the Gulf of Mexico after the DH oil spill [28, 3032]. Moreover, Rhodobacteracea are known to be primary surface-colonizing bacteria in temperate coastal ecosystems, allowing other bacteria to colonize and grow on surfaces [33].

Band D appeared in all tar ball samples with relatively consistent intensity (Fig. 1). The characterized genus closest to the 16S rRNA gene sequence in band $\mathrm{D}$ was Aquisalimonas (Table 1). Thus far, only three species of Aquisalimonas have been described - A. asiatica, A. halophila, and A. lutea - all of which are moderately halophilic and unable to survive in salinity concentrations lower than $1 \%$ [34-36]. The dominance of band D under the low salinity condition suggests a novel Aquisalimonas species that thrive in salinity concentrations lower than $1 \%$, however, further study is necessary to confirm this observation. There has been no report on the pathogenicity of the three Aquisalimonas spp.

Band $\mathrm{E}$ was detected only in the tar ball samples incubated in sterilized DI-water for six months. As mentioned above, the bacterial species representing band $\mathrm{E}$ was indigenous to the marine tar balls, since no microorganisms were introduced in the microcosms. Therefore, it is likely that the abundance of species $\mathrm{E}$ in marine tar balls was below the 
108

109

110

111

112

113

114

115

116

117

118

119

120

121

122

123

124

125

126

127

128

129

130

131

132

detection limit of DGGE and increased under low salinity conditions [37]. DNA sequencing of this band showed that the species was closely related to Parvibaculum sp. MBNA2 (Table 1). This bacterial strain was previously isolated from freshwater sediments and a brackish water mud [38,39]. Oiled wetland sediment and sea water samples collected in December 2010 along the Gulf of Mexico were reported to contain a large bacterial population affiliated with the genus Parvibaculum, [31]. Previous research has reported Parvibaculum spp. capable of degrading various hydrocarbon compounds, including PAH, alkanes, and surfactants [40-42]. No known human pathogens were reported belonging to the genus Parvibaculum.

In this research, we demonstrated that the indigenous bacterial community of marine tar balls was shifted when exposed to low salinity conditions and that dominant bacterial species in the tar balls at low salinity conditions were not phylogenetically close to potential human pathogens. The steep decline in salinity is most likely the major factor affecting the bacterial communities. However, this research did not consider other possible effectors during tar balls' migration from the ocean to estuarine or inland water bodies, such as an introduction of exogenous bacteria and other environmental factors (e.g., temperature, $\mathrm{pH}$, dissolved oxygen, and dissolved nutrients). We expect that our study provides preliminary data to support further research on pathogens in estuarine tar balls.

Acknowledgements: We thank Dr. Ahjeong Son at Auburn University (currently at Ewha Womans University) for providing tar ball samples. This work was supported by the Chancellor's Fellowships and the Faculty Development Research grants, Troy University, Troy AL, and by the Beta Beta Beta Research Scholarship Foundation, Beta Beta Beta National Biological Honor Society.

Conflict of Interest: The authors declare no conflict of interest.

\section{References}

1. Oil in the sea III: inputs, fates, and effects. National Academies Press, Washington, D.C., USA, 2003. Available online: http://www.nap.edu/catalog/10388/oil-in-the-sea-iii-inputs-fates-and-effects (accessed on 12 September 2017) 
133

134

135

136

137

138

139

140

141

142

143

144

145

146

147

148

149

150

151

152

153

154

155

156

157

158

159

160

2. Wang, P.; Roberts, T.M. Distribution of surficial and buried oil contaminants across sandy beaches along NW Florida and Alabama coasts following the Deepwater Horizon oil spill in 2010. J. Coast Res. 2013, 29, 144-155.

3. Goodman, R. Tar balls: the end state. Spill Sci. Technol. Bull. 2003, 8, 117-121.

4. Lorenson, T.D.; Hosteller, F.D.; Rosenbauer, R.J.; Peters, K.E.; Dougherty, J.A.; Kvenvolden, K. A.; Gutmacher, C.E.; Wong, F.L.; Normark, W.R. Natural offshore oil seepage and related tarball accumulation on the California Coastline - Santa Barbara Channel and the Southern Santa Maria Basin; source identification and inventory. Geological Survey Report No. 2009-1225. Department of the Interior, USA, 2009; pp. 119.

5. Aeppli, C.; Carmichael, C. A.; Nelson, R. K.; Lemkau, K.L.; Graham, W. M.; Redmond, M.C.; Valentine, D.L.; Reddy C.M. Oil weathering after the Deepwater Horizon disaster led to the formation of oxygenated residues. Environ. Sci. Technol. 2012, 46, 8799-8807.

6. Liu, Z.; Liu, J.; Zhu, Q.; Wu, W. The weathering of oil after the Deepwater Horizon oil spill: insights from the chemical composition of the oil from the sea surface, salt marshes and sediments. Environ. Res. Lett. 2012, 7 , 035302.

7. Operational Science Advisory Team (OSAT). Summary report for fate and effects of remnant oil in the beach environment. Update Feb 2011, cited Aug 13, 2015. Available online: http://www.restorethegulf.gov/sites/default/files/u316/OSAT-2\%20Report\%20no\%20ltr.pdf (accessed on 12 September 2017)

8. Warnock, A.M.; Hagen, S. C.; Passeri, D.L. Marine tar residues: a review. Water, Air, Soil Pollut. 2015, 226, 68.

9. Kiruri, L.W.; Dellinger, B.; Lomnicki, S. Tar balls form Deep Water Horizon oil spill: environmentally persistent free radicals (EPFR) formation during crude weathering. Environ. Sci. Technol. 2013. 47, 4220-4226.

10. Wise, Jr. J.P.; Wise, J.T.F.; Wise, C.F.; Wise, S.S.; Gianios, C.; Xie, H.; Thompson, W.D.; Perkins, C.; Falank, C.; Wise, Sr. J.P. Concentrations of the genotoxic metals, chromium and nickel, in whales, tar balls, oil slicks, and released oil from the Gulf of Mexico in the immediate aftermath of the deepwater horizon oil crisis: is genotoxic metal exposure part of the deepwater horizon legacy? Environ. Sci. Technol. 2014, 48, 2997-3006.

11. Tao, Z.; Bullard, S.; Arias, C. High numbers of Vibrio vulnificus in tar balls collected from oiled areas of the north-central Gulf of Mexico following the 2010 BP Deepwater Horizon oil spill. Ecohealth 2011, 8, 507-511.

12. Gulf Coast oil disaster: tar balls hit Lake Pontchartrain shores. CNN, Update Jul 2010. Available online: http://www.cnn.com/2010/US/07/05/gulf.oil.pontchartrain/ (accessed on 12 September 2017) 
161

162

163

164

165

166

167

168

169

170

171

172

173

174

175

176

177

178

179

180

181

182

183

184

185

186

187

188

13. Nearly 1,700 pounds of oil captured in Lake Pontchartrain. Times-Picayune, Update Jul 2010. Available online: http://www.nola.com/news/gulf-oil-spill/index.ssf/2010/07/nearly_17000_pounds_of_oil_cap.html (accessed on 12 September 2017)

14. Oren, A. The bioenergetic basis for the decrease in metabolic diversity at increasing salt concentrations: Implications for the functioning of salt lake ecosystems. Hydrobiologia 2001, 466, 61-72.

15. Zhang, L.; Gao, G.; Tang, X.; Shao, K. Impacts of different salinities on bacterial biofilm communities in fresh water. Can. J. Microbiol. 2014, 60, 319-326.

16. Jurelevicius, D.; Alvarez, V.M.; Marques, J.M.; de Sousa Lima, L.R.; Dias Fde, A.; Seldin, L. Bacterial community response to petroleum hydrocarbon amendments in freshwater, marine, and hypersaline watercontaining microcosms. Appl. Environ. Microbiol. 2013, 79, 5927-5935.

17. Rodrigues, C.S.; Souza, S.S.; Rezende, R.P.; Silva, A.; Andrioli, J.L.; Costa, H.; Fontana R.; Dias J.C. Application of denaturing gradient gel electrophoresis for detection of bacterial and yeast communities along a salinity gradient in the estuary of the Cachoeira River in Brazil. Genet. Mol. Res. 2013, 12, 1752-1760.

18. They, N.H.; Ferreira, L.M.; Marins, L.F.; Abreu, P.C. Bacterial community composition and physiological shifts associated with the El Niño Southern Oscillation (ENSO) in the Patos Lagoon Estuary. Microb. Ecol. 2014, 69, $525-534$.

19. Muyzer, G.; de Waal, E.C.; Uitterlinden, A.G. Profiling of complex microbial populations by denaturing gradient gel electrophoresis analysis of polymerase chain reaction-amplified genes coding for 16S rRNA. Appl. Environ. Microbiol. 1993, 59, 695-700.

20. Altschul, S.F.; Gish, W.; Miller, W.; Lipman, D.J. Basic local alignment search tool. J. Mol. Biol. 1990, 215, $403-410$.

21. Estuarine salinity zones in Gulf of Mexico atlas. National Coastal Data Development Center (NCDDC) - National Oceanic and Atmospheric Administration (NOAA). Available online: http://www.ncddc.noaa.gov/website/DataAtlas/atlas.htm?plate=Salinity\%20-\%20Zones $\quad$ (accessed on 12 September 2017)

22. Kessler, J.D.; Valentine, D.L.; Redmond, M.C.; Du, M.; Chan, E.W.; Mendes, S.D.; Quiroz E.W.; Villanueva C.J.; Shusta S.S.; Werra L.M.; Yvon-Lewis S.A.; Weber T.C. A persistent oxygen anomaly reveals the fate of spilled methane in the deep Gulf of Mexico. Science 2011, 331, 312-315. 
23. Mason, O.U.; Hazen, T.C.; Borglin, S.; Chain, P.S.; Dubinsky, E.A.; Fortney, J.L.; Han J.; Holman H.Y.; Hultman J.; Lamendella R.; Mackelprang R.; Malfatti S.; Tom L.M.; Tringe S.G.; Woyke T.; Zhou J.; Rubin E.M.; Jansson J.K. Metagenome, metatranscriptome and single-cell sequencing reveal microbial response to Deepwater Horizon oil spill. ISME J. 2012, 6, 1715-1727.

24. Kimes, N.E.; Callaghan, A.V.; Suflita, J.M.; Morris, P.J. Microbial transformation of the Deepwater Horizon oil spill: past, present, and future perspectives. Front. Microbiol. 2014, 5, 1-11.

25. Gray, N.D.; Sherry, A.; Hubert, C.; Dolfing, J.; Head, I.M. Methanogenic degradation of petroleum hydrocarbons in subsurface environments remediation, heavy oil formation, and energy recovery. Adv. Appl. Microbiol. 2010, 72, 137-161.

26. Berdugo-Clavijo, C.; Gieg, L.M. Conversion of crude oil to methane by a microbial consortium enriched from oil reservoir production waters. Front. Microbiol. 2014, 5, 197.

27. Mohn, W.W.; Mertens, B.; Neufeld, J.D.; Verstraete, W.; De Lorenzo, V. Distribution and phylogeny of hexachlorocyclohexane-degrading bacteria in soils from Spain. Environ. Microbiol. 2006, 8, 60-68.

28. Kostka, J.E.; Prakash, O.; Overholt, W.A.; Green, S.J.; Freyer, G.; Canion, A.; Delgardio J.; Norton N.; Hazen T.C.; Huettel M. Hydrocarbon-degrading bacteria and the bacterial community response in Gulf of Mexico beach sands impacted by the deepwater horizon oil spill. Appl. Environ. Microbiol. 2011, 47, 7962-7974.

29. Wang, W.; Zhong, R.; Shan, D.; Shao, Z. Indigenous oil-degrading bacteria in crude oil-contaminated seawater of the Yellow Sea, China. Appl. Microbiol. Biotechnol. 2014, 98, 7253-7269.

30. Redmond, M.; Valentine, D. Natural gas and temperature structured a microbial community response to the Deepwater Horizon oil spill. PNAS 2012, 109, 20292-20297.

31. Looper, J.K.; Cotto, A.; Kim, B.Y.; Lee, M.K.; Liles, M.R.; Ní Chadhain, S.M.; Son A. Microbial community analysis of Deepwater Horizon oil-spill impacted sites along the Gulf coast using functional and phylogenetic markers. Environ. Sci. Process Impacts 2013, 15, 2068-2079.

32. Newton, R.J.; Huse, S.M.; Morrison, H.G.; Peake, C.S.; Sogin, M.L.; McLellan, S.L. Shifts in the microbial community composition of Gulf coast beaches following beach oiling. PLoS One 2013, 8, 1-13.

33. Dang H.; Li T.; Chen M.; Huang, G. Cross-ocean distribution of Rhodobacterales bacteria as primary surface colonizers in temperate coastal marine waters. Appl. Environ. Microbiol. 2008, 74, 52-60. 
34. Márquez, M.C.; Carrasco, I.J.; Xue, Y.; Ma, Y.; Cowan, D.A.; Jones, B.E.; Grant W.D.; Ventosa A. Aquisalimonas asiatica gen. nov., sp. nov., a moderately halophilic bacterium isolated from an alkaline, saline lake in Inner Mongolia, China. Int. J. Syst. Evol. Microbiol. 2007, 57, 1137-1142.

35. Zhang, Y.J.; Jia, M.; Ma, Y.C.; Lu, K.Y.; Tian, F.; Klenk, H.P.; Zhou Y.; Tang S.K. Aquisalimonas halophila sp. nov., a moderately halophilic bacterium isolated from a hypersaline mine. Int. J. Syst. Evol. Microbiol. 2014, 64, $2210-2216$.

36. Infante-Dominguezm, C.; Sanchez-Porro, C.; Ventosa, A. Aquisalimonas lutea sp. nov., a moderately halophilic bacterium from a saltern. Int. J. Syst. Evol. Microbiol. 2015, 65, 1354-1359.

37. Park, J.W.; Crowley, D.E. Normalization of soil DNA extraction for accurate quantification of target genes by real-time PCR and DGGE. Biotechniques 2005, 38, 579-586.

38. Straub, K.L.; Benz, M.; Schink, B.; Widdel, E. Anaerobic, nitrate-dependent microbial oxidation of ferrous iron. Appl. Environ. Microbiol. 1996, 62, 1458-1460.

39. Blöthe, M.; Roden, E.E. Composition and activity of an autotrophic Fe(II)-oxidizing, nitrate-reducing enrichment culture. Appl. Environ. Microbiol. 2009, 75, 6937-6940.

40. Schleheck, D.; Tindall, B.J.; Rosselló-Mora, R.; Cook, A.M. Parvibaculum lavamentivorans gen. nov., sp. nov., a novel heterotroph that initiates catabolism of linear alkylbenzenesulfonate. Int. J. Syst. Evol. Microbiol. 2004, $54,1489-1497$.

41. Hilyard, E.J.; Jones-Meehan, J.M.; Spargo, B. J.; Hill, R.T. Enrichment, isolation, and phylogenetic identification of polycyclic aromatic hydrocarbon-degrading bacteria from Elizabeth River sediments. Appl. Environ. Microbiol. 2008, 74, 1176-1182.

42. Wang, W.; Wang, L.; Shao, Z. Diversity and abundance of oil-degrading bacteria and alkane hydroxylase (alkB) genes in the subtropical seawater of Xiamen Island. Microb. Ecol. 2010, 60, 429-439. 
bioRxiv preprint doi: https://doi.org/10.1101/241034; this version posted December 29,2017 . The copyright holder for this preprint (which was not certified by peer review) is the author/funder, who has granted bioRxiv a license to display the preprint in perpetuity. It is made available under aCC-BY-NC-ND 4.0 International license.

238 Table 1. Close relatives of partial 16S rRNA genes obtained from major DGGE gel bands

\begin{tabular}{clcc}
\hline Band & Close relative in GenBank databases & $\begin{array}{c}\text { GenBank } \\
\text { Accession \# }\end{array}$ & \% Identity \\
\hline A & Methylocystaceae bacterium PKR-39 & KJ000026 & 85 \\
B & Novosphingobium panipatense, isolate 1111TES1A3 & LN774374 & 90 \\
C & Rhodobacterales bacterium PSMR052 & KJ995712 & 96 \\
D & Aquisalimonas halophila YIM 95345 & KC577145 & 91 \\
E & Parvibaculum sp. MBNA2 & FN430653 & 97 \\
\hline
\end{tabular}




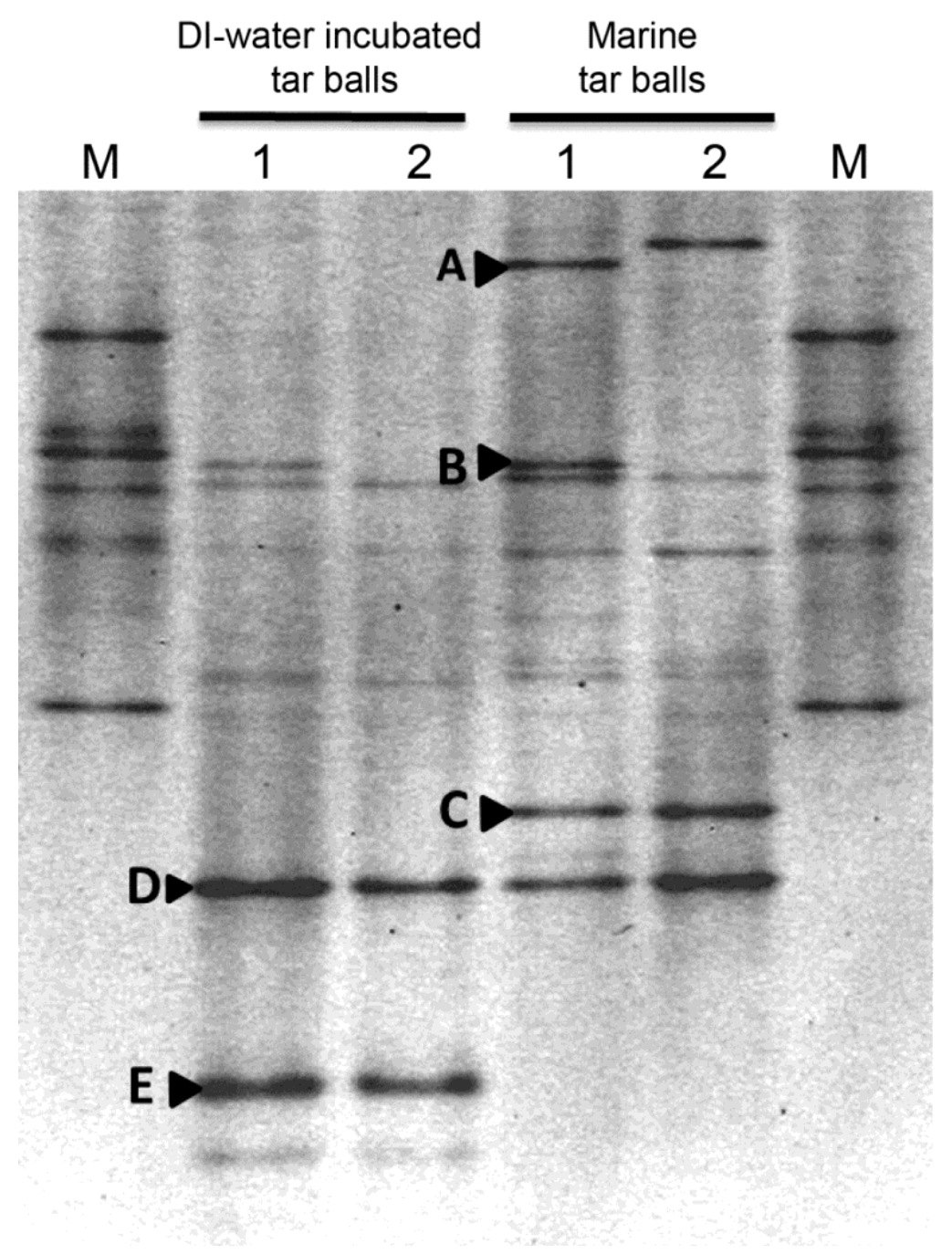

242 Figure 1. Bacterial community shift after exposure to low salinity conditions. Bacterial 16S rRNA gene profiles in

243 untreated marine tar balls (Marine tar balls) and tar balls after six-month of incubation in deionized water (DI-water

244 incubated tar balls) were analyzed by DGGE. Bands A to E were selected for sequencing. M: custom marker; numbers

2451 and 2 are duplicates. 